\title{
2. Freshwater Ecosystem Conservation: Principles versus policy
}

\author{
Jamie Pittock, C. Max Finlayson
}

\section{Introduction}

The Ramsar Convention on Wetlands and the Convention on Biological Diversity provide much of the constitutional mandate for the Australian Water Act 2007 and proposed Murray-Darling Basin Plan, due to be adopted in 2011. The Plan is meant to give effect to these international agreements by reducing excessive water diversions to environmentally sustainable levels, using environmental flows to conserve key ecological assets such as wetlands, manage emerging risks to water supplies and then optimise socioeconomic benefits. The policies proposed in the October 2010 Guide to the proposed Basin Plan fail, however, the fundamental test in the Ramsar Convention-namely, maintaining the ecological character of wetlands. The proposed return of 3000-4000 gigalitres per annum on average to the environment is insufficient to conserve more than 75 per cent of the red-gum floodplain forests and designated Ramsar Wetlands of International Importance - or a representative range of wetland types. The threat to wetlands would be exacerbated by the minimal measures proposed to manage emerging risks to water supplies with climate change.

We conclude that the measures proposed in the Guide are insufficient to fulfil Australia's Ramsar Convention obligations, and recommend seven additional measures, including the return of 4000-7600 GL/year of water to conserve Ramsar wetlands. Other required improvements include undertaking a rigorous assessment of ecosystem services and of representation of biota in key ecological assets, protection of remaining unregulated water flows, more robust precautions to adapt to climate change, reoperating water infrastructure and identifying priorities for research to improve the subsequent iteration of the Basin Plan.

In its dryness, Australia suggests the Planet's future, as the vast human population and the demands of its industries intensify competition for an unchanging quantity of freshwater; in water terms, Australia is a warning, and Chowilla [floodplain forests of the Murray-Darling Basin] is its immediate expression. The Chowilla red gums are part of a vast death event, encompassing hundreds of thousands, perhaps millions of trees...extending six hundred miles. (Leslie 2005:223) 
In this chapter, we focus on management steps needed to sustain the freshwater ecosystems and other biodiversity of the Murray-Darling Basin(MDB). Although the Basin is located entirely within Australia, its management holds lessons for the conservation of an increasing number of river basins globally (Falkenmark and Molden 2008; Pearce 2006; Powell 2008). We begin by summarising the key features of a number of conservation treaties that Australia signed and upon which the Federal Government derives a large portion of its constitutional mandate for management of the Basin. The status and trends of freshwater ecosystems of the Basin, and past management responses, are described only briefly as they are covered in existing authoritative publications.

We then focus on the requirements of the Commonwealth Water Act (Commonwealth of Australia 2007) to develop a Basin Plan to 'give effect to relevant international agreements' by maintaining and restoring environmental assets through a return to 'environmentally sustainable levels' of extraction of water resources (MDBA 2010a:xii). The ecological and risk-management measures suggested in the first step in meeting this requirement - the Guide to the proposed Basin Plan (MDBA 2010a) - are then assessed, and conclusions are drawn on the extent to which the mooted policies would fulfil conservation principles, and international and national legal obligations for freshwater conservation. In particular, we focus on whether the proposed measures would conserve a representative range of wetland types, sustain the ecological character of the wetlands across the Basin, and adequately manage climate change-induced risks. Finally, further measures are recommended to ensure the survival of freshwater ecosystems in the Basin.

\section{The International Context}

In this chapter, the freshwater biome-which embraces rivers, floodplains, groundwater-dependent ecosystems, lakes and estuaries - is interchangeably described as: 'inland waters' biodiversity, as defined by the Convention on Biological Diversity (CBD); wetlands, as defined by the Ramsar Convention on Wetlands (Ramsar); and freshwater ecosystems. Ramsar defines wetlands broadly to embrace all freshwater plus coastal ecosystems to $6 \mathrm{~m}$ depth (Ramsar 2009a). Globally, freshwater ecosystems are especially threatened, over-exploited and poorly conserved (MEA 2005b; Pittock et al. 2008).

Starting in the 1970s, Australia joined other countries in adopting multilateral environmental agreements and in developing conservation targets and measures to conserve freshwater biodiversity. These actions were taken in response to growing concerns about the state of ecosystems around the world. The CBD commits member states to the conservation and sustainable use of biodiversity, which in the freshwater context has been elaborated through programs of work 
on protected areas and on the conservation of inland waters' biodiversity (CBD 2004a, 2004b; United Nations 1992). More specifically, the Ramsar Convention on Wetlands commits contracting parties to the wise use (ecologically sustainable development) of all wetlands, and to maintain the ecological character of all designated Ramsar wetlands of international significance (Pittock et al. 2010; Ramsar 2009a); 16 wetlands have been designated as Ramsar sites in the Murray-Darling Basin (DEWHA 2009). A common principle of both the CBD and Ramsar - and an obligation on their members - is the identification, conservation and protection of sites that are representative of the diversity of freshwater ecosystems (CBD 2004b; Ramsar 2008b), such as the different wetland types identified by Ramsar (2009b). Australia is also a member of a number of bilateral and multilateral conventions for the conservation of migratory species-notably for waterbird species, whose populations are declining (Finlayson et al. 2006).

These environmental agreements have weak enforcement provisions in international law, but they are significant in providing a constitutional mandate for the Federal Government to enact legislation to implement Australia's obligations (Pittock et al. 2010). Thus, the Basin Plan and other measures under the Water Act 2007 are intended to faithfully reflect provisions of the conventions. If they were substantially inconsistent with the conventions their validity may be challenged in the courts (Pittock et al. 2010). Consequently, this assessment considers whether the conservation measures proposed in the Guide give effect to the CBD and Ramsar agreements by fulfilling relevant conservation requirements, including the conservation of adequate and representative examples of freshwater ecosystems, conservation of threatened species, and maintenance of the ecological character of designated Ramsar wetlands. Further, the Water Act requires management of risk-in particular, of changes in hydrology due to climate change (Commonwealth of Australia 2007). This assessment looks at the effectiveness of the proposed management of the risk to freshwater ecosystems from climate-induced changes to hydrology.

\section{Freshwater Ecosystems of the Basin}

The Murray-Darling Basin covers 1061500 sq km (Figure 2.1) and contains the longest river system in Australia. The high-rainfall mountain districts in the east account for 5 per cent of the area and yet contribute more than 50 per cent of the run-off (CSIRO 2008). The MDB has diverse species and ecosystems, nearly $57000 \mathrm{sq} \mathrm{km}$ of wetlands, and 16 wetlands covering $6363 \mathrm{sq} \mathrm{km} \mathrm{listed} \mathrm{as}$ internationally important under Ramsar (DEWHA 2009; Kingsford et al. 2004; MDBA 2010a, 2010b). By distinguishing between $60000 \mathrm{sq} \mathrm{km}$ of floodplains and $25000 \mathrm{sq} \mathrm{km}$ of 'wetlands', the Murray-Darling Basin Authority (MDBA 2010a:59) does not appear to understand the broad definition of a wetland under the Ramsar Convention. 


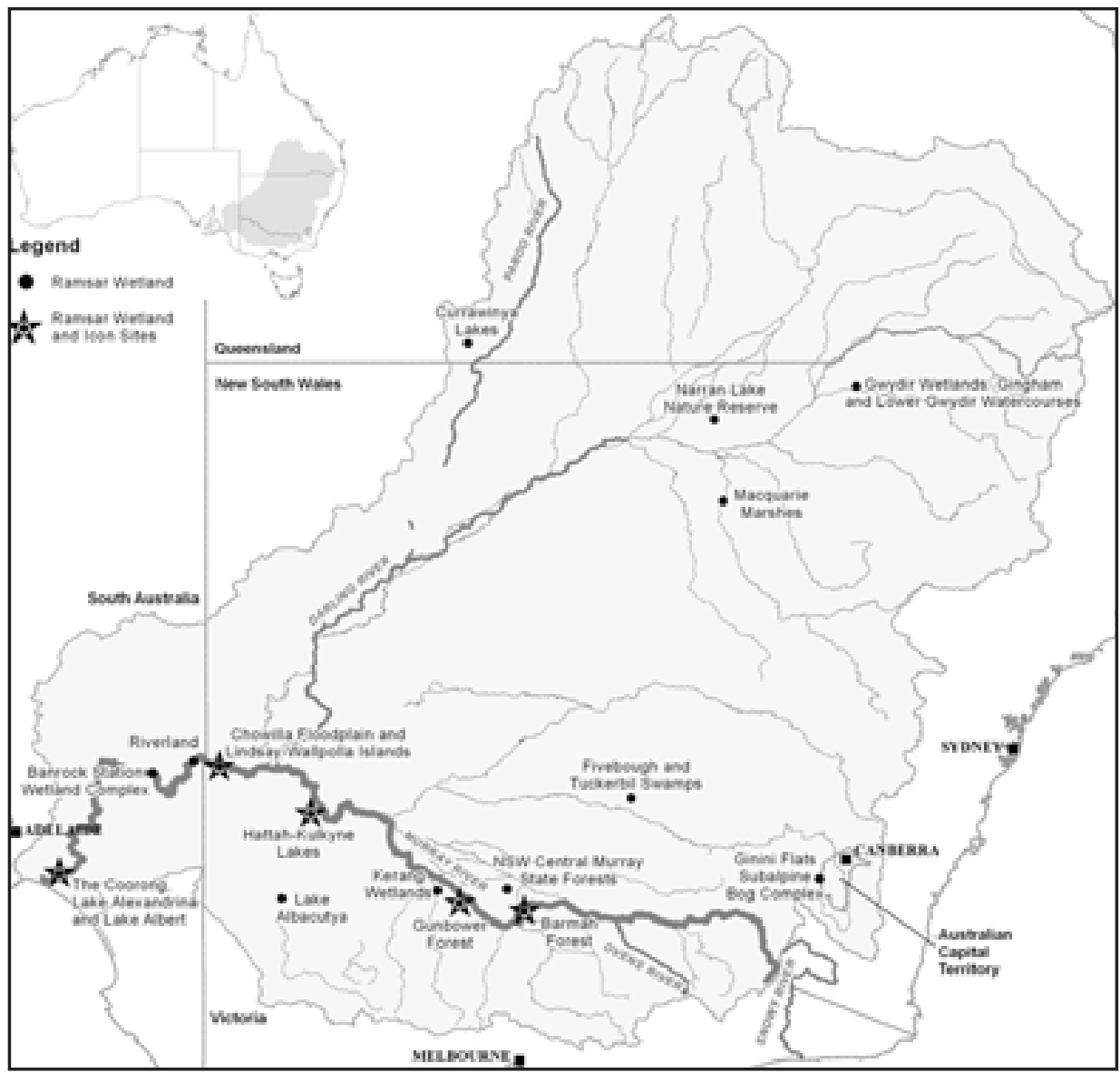

Figure 2.1 The Murray-Darling Basin showing the location of designated Ramsar wetlands

A 2007 audit of the 23 river valleys in the Basin found that only one was in good condition versus five classified as moderate, nine as poor, and eight as very poor (Davies et al. 2010). The condition of freshwater ecosystems of the Basin depends substantially upon adequate water flows of the right quality and at the right time. Flood pulses are particularly important, but their frequency has been greatly reduced such that only one-quarter of the active floodplain in the Basin had been inundated in nine years - a period approaching the tolerance thresholds of some floodplain species (Overton et al. 2009). Importantly, different wetland ecological communities lie on an inundation (or elevation) gradient on the floodplain, and thus a reduction of environmental flows disproportionately impacts on wetlands on the higher reaches of floodplains, such as black-box floodplain forest (NRC 2009; Overton 2010). Further, as river 
flows are diminished upstream in wetlands or through extractions, over-bank flood frequency diminishes further down the rivers and the ecological impacts increase (CSIRO 2008).

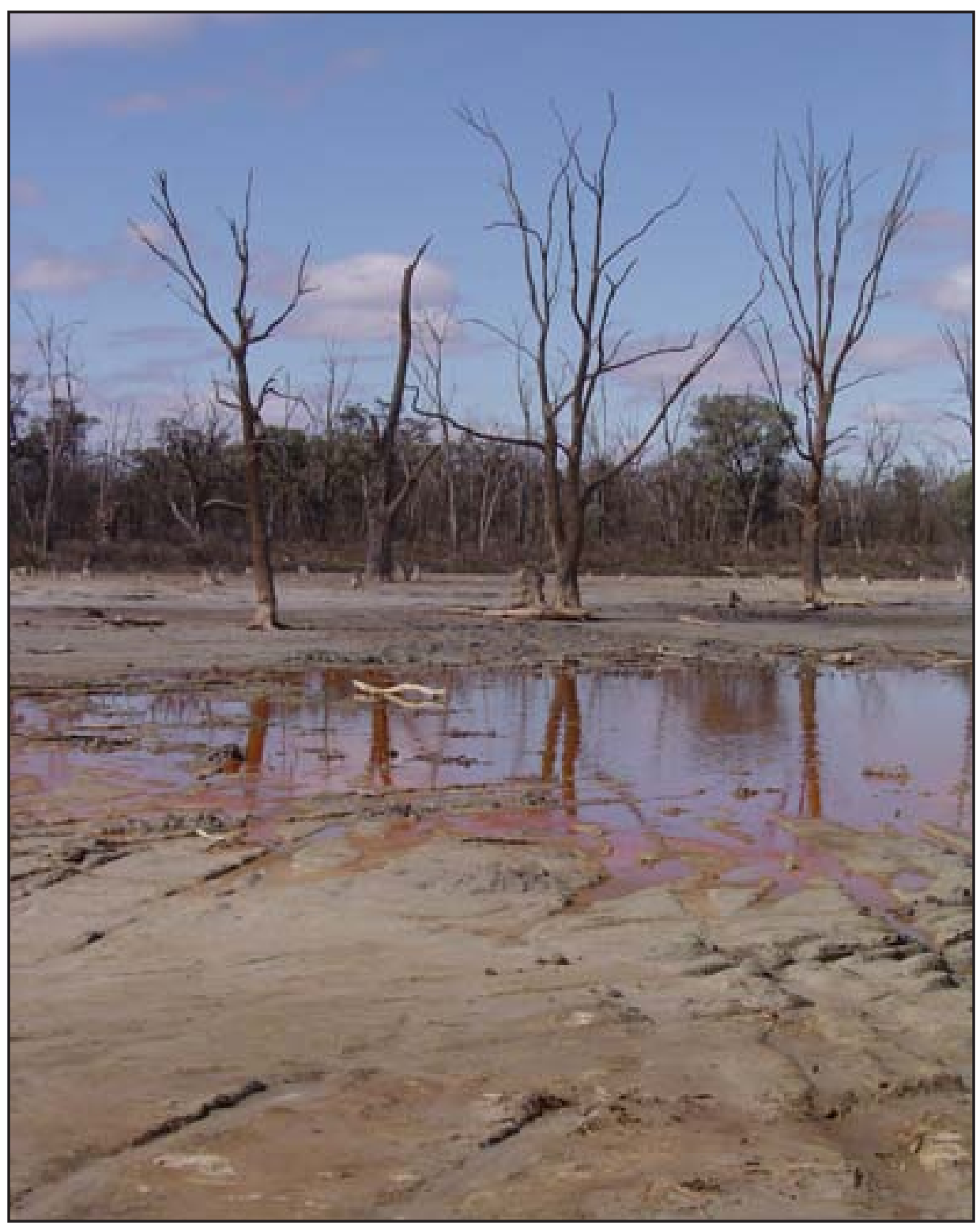

Figure 2.2 Psyche Bend Lagoon on the floodplain of the River Murray near Mildura, Victoria, showing the impact of reduced environmental flows that have led to salinisation, acidification and the death of wetland vegetation 
The Basin's freshwater ecosystems are declining primarily as a result of over-extraction of water for consumptive uses - a threat that might now be exacerbated by climate change (Pittock et al. 2010). Expressions of this decline include the death of extensive areas of floodplain forests and their replacement with terrestrial species, toxic cyanobacteria blooms, increasing salinity, oxidation of sulphate soils to form sulphuric acid, declines in waterbird and native fish populations, and expansion of invasive species (Pittock and Finlayson 2011; Pittock et al. 2010). A number of these changes might be difficult if not impossible to reverse, involving such elements as the deaths of trees that are hundreds of years old and changes to the chemistry of sediments (Figure 2.2). For these reasons, the restoration of water flows of adequate volume, quality and timing is essential to sustain ecological assets.

Irrigated land covers only 2 per cent of the Basin yet uses 90 per cent of diverted waters to produce 70 per cent of Australia's irrigated agricultural outputvalued at A\$7 billion per year (ABS et al. 2009). With increasing concern over the state of the river and its wetlands, the MDBA (2010a:xiv) states: 'The real possibility of environmental failure now threatens the long-term economic and social viability of many industries and the economic, social and cultural strength of many communities.'

\section{Past Efforts to Restore the Basin's Wetlands}

The European history of the Basin is marked by a sequence of attempts to reform management (Connell 2007). In recent decades, the failure of previous institutional reform has been exposed by another ecological crisis, sparking the adoption of yet another reform effort. Three recent measures adopted for ecological conservation are worth noting in an analysis of the likely effect of the policies proposed in the Guide. First, under the National Water Initiative (NWI) (COAG 2004), the State governments agreed to prepare water-sharing plans for all rivers, yet New South Wales in 2006 and Victoria in 2007 suspended their plans as the 'drought' from 2002 deepened, highlighting the sovereign risk that bedevils river-conservation measures (NWC 2009).

Second, a number of government programs were established to recover water through efficiency measures because of the perceived benefits for both irrigated agriculture and the environment. These measures proved, however, to be an 'efficiency trap' because they were: slow and unreliable in returning water to the environment, double counting leaking water that returned to the environment, unfairly subsidising inefficient farmers, and risking investing in infrastructure that could become stranded (Grafton and Hussey 2007; Productivity Commission 2010). 
Finally, governments prioritised investments in 'environmental works and measures', and engineered structures to enable the use of less water to maintain larger areas of wetlands (Pittock and Lankford 2010). In part this was due to a decision by the governments to reallocate just $500 \mathrm{GL} / \mathrm{yr}$ to the River Murray (MDBMC 2003) - a manifestly inadequate volume to sustain major wetlands (Jones et al. 2002) - and the resulting need to make such a small volume deliver greater environmental benefits. There was, however, little consideration of the path dependency this infrastructure establishes, the resulting fragmentation of riverine ecosystems by weirs, levees and channels, or the need for ongoing and high-quality management interventions for this strategy to be successful (Pittock and Finlayson 2011). Indeed, the opportunity cost of this expensive infrastructure has not been considered by governments when the same funds could purchase sufficient water entitlements to make these engineering measures largely redundant (Kingsford et al. 2009; Pittock et al. 2010).

The modest targets adopted by governments in 2003 to conserve iconic wetlands along the River Murray had failed by 2009, with extensive loss of floodplain forests, including in designated Ramsar wetlands (Pittock et al. 2010). The lesson from the unsuccessful attempts to use water-sharing plans, agricultural water-use efficiency and environmental water demand management measures to sustain the health of freshwater ecosystems is that trying to manage the Basin with maximum water-use efficiency leaves no room for error; unplanned events such as poor governance, changes in water use, drought or extreme climate change will derail institutions that lack resilience. We argue that these types of events should be better anticipated and the risks proactively managed. The measures proposed in the Water Act and the Guide to the proposed Basin Plan were assessed in this context.

\section{The Water Act}

The Water Act established the MDBA with a remit to develop and supervise a framework for the management of the Basin's water in the national interest. The Authority is required to: give effect to relevant international agreements; conserve ecological values and ecosystem services; reduce water extraction to environmentally sustainable levels; and, subject to this, optimise socioeconomic and environmental outcomes (Commonwealth of Australia 2007). The Basin Plan is the primary instrument for implementing the Act.

In October 2010, the Authority published the Guide to the proposed Basin Plan for public comment (MDBA 2010a). The MDBA is scheduled to publish a draft plan in early 2011 before submitting a final plan for the minister's consideration 
in late 2011. We now critique the proposals in the Guide and conclude by suggesting changes required to adequately implement international agreements, conserve ecological values and maintain ecosystem services.

\section{Proposals in the Guide to the proposed Basin Plan}

\section{The Thresholds for Sustainable Take}

The question of an environmentally sustainable level of take is in part a value judgment since the freshwater ecosystems of the Basin evolved with all the available water, and regular extraction of any large amount of water will have a greater or lesser environmental impact. The Water Act says that the environmentally sustainable level of take must not compromise: key ecosystem functions, key environmental assets, the productive base and the key environmental outcomes for the water resource (MDBA 2010a:xvii). The CBD and Ramsar have, however, more specific principles that should be used to determine the extent of the freshwater ecosystems to conserve (CBD 2004a, 2004b; Ramsar 2008b, 2009b). These are

- designated wetlands protected areas, such as Ramsar sites

- habitats of threatened biota

- habitats of migratory species

- important breeding habitat for biota such as fish

- comprehensive, adequate and representative examples of each wetland type and the habitat of species dependent on aquatic ecosystems.

The approach adopted by the MDBA (2010a:63) applies five criteria-namely, for: the presence of listed migratory species; natural, rare or unique ecosystems; 'vital' habitat; habitat of listed threatened species or ecosystems; and supporting 'significant' biodiversity. In particular, no effort has been made to identify representative examples of wetland biota for conservation as required by the two conventions. While many wetland types would be conserved through a system of environmental flows that maintain ecological processes, others will not. The wetland types that could be overlooked include those that are: on higher elevations of floodplains (for example, black-box floodplain forests), in the higher parts of catchments and minor tributaries (for example, tableland wetlands), or are disconnected from the rivers (for example, groundwaterdependent ecosystems). 


\section{Wise Use of All Wetlands}

In addition, the Ramsar Convention (2005:Cl. 11) requires the 'wise use' of all wetlands, which is defined as 'the maintenance of their ecological character, achieved through the implementation of ecosystem approaches, within the context of sustainable development'. 'Ecological character' is defined as: 'the combination of the ecosystem components, processes and benefits/services that characterise the wetland at a given point in time' (Ramsar 2008a:Cl. 15). Consequently, the Australian Government may not decide to change the character of significant areas of wetlands, and the various services that they provide, and adhere to the Ramsar Convention. The proposal not to conserve 25 per cent of the red-gum forests, and, as a result, larger areas of black box and other wetlands that are less frequently watered, amounts to a significant change in wetlands character (Pittock et al. 2010).

\section{Ecosystem Services}

The Water Act 2007 has an objective 'to protect, restore and provide for the ecological values and ecosystem services' (Commonwealth of Australia 2008:s. 3[d][ii]). This is, however, not clearly linked to the 'key ecosystem functions' that the Water Act specifies should not be compromised in determining the environmentally sustainable level of take (MDBA 2010a:xvii). The Guide scarcely mentions ecosystem services, but extensively considers ecosystem functions, which are defined as: 'the fundamental physical, chemical and biological processes that support the Basin's environmental assets' (Commonwealth of Australia 2008:59; see also Alluvium 2010).

Curiously, the Act and the MDBA do not draw on international academic literature or the conventions to place these concepts in a broader context. Ecosystem services (called 'ecosystem benefits/services' by Ramsar) are defined as 'the benefits that people receive from ecosystems' (Ramsar 2005:Cl. 11). International environmental institutions are increasingly adopting ecosystem services as a framework for their work, including Ramsar, the CBD and, most recently, the Intergovernmental Science-Policy Platform on Biodiversity and Ecosystem Services (IPBES 2010). Ecosystem services have a broader, defined typology for describing and managing the different regulating, cultural, supporting and provisioning services (MEA 2005a; Ramsar 2005) - an approach that brings together ecological and socioeconomic values. What the MDBA calls ecosystem functions are clearly just a subset of the regulating and supporting ecosystem services. The failure of the Basin Plan process to fully use the ecosystem-services approach risks omitting measures required to maintain key services and misses an opportunity to more cogently assess and explain the links between a healthy ecosystem and the wellbeing of people in the Basin (Figure 2.3). 
The lack of consideration of ecosystem services in the Guide highlights the MDBA's evident lack of understanding of the definitions, relevance and application of key concepts of the Ramsar Convention. In particular, the Ramsar definition of wetlands is not applied, ecological character and ecosystem services are cited only in passing, and representativeness is omitted entirely. This is a questionable approach to faithfully implementing the conventions, which the proposed Basin Plan needs to demonstrate if it is to justify its constitutional mandate.

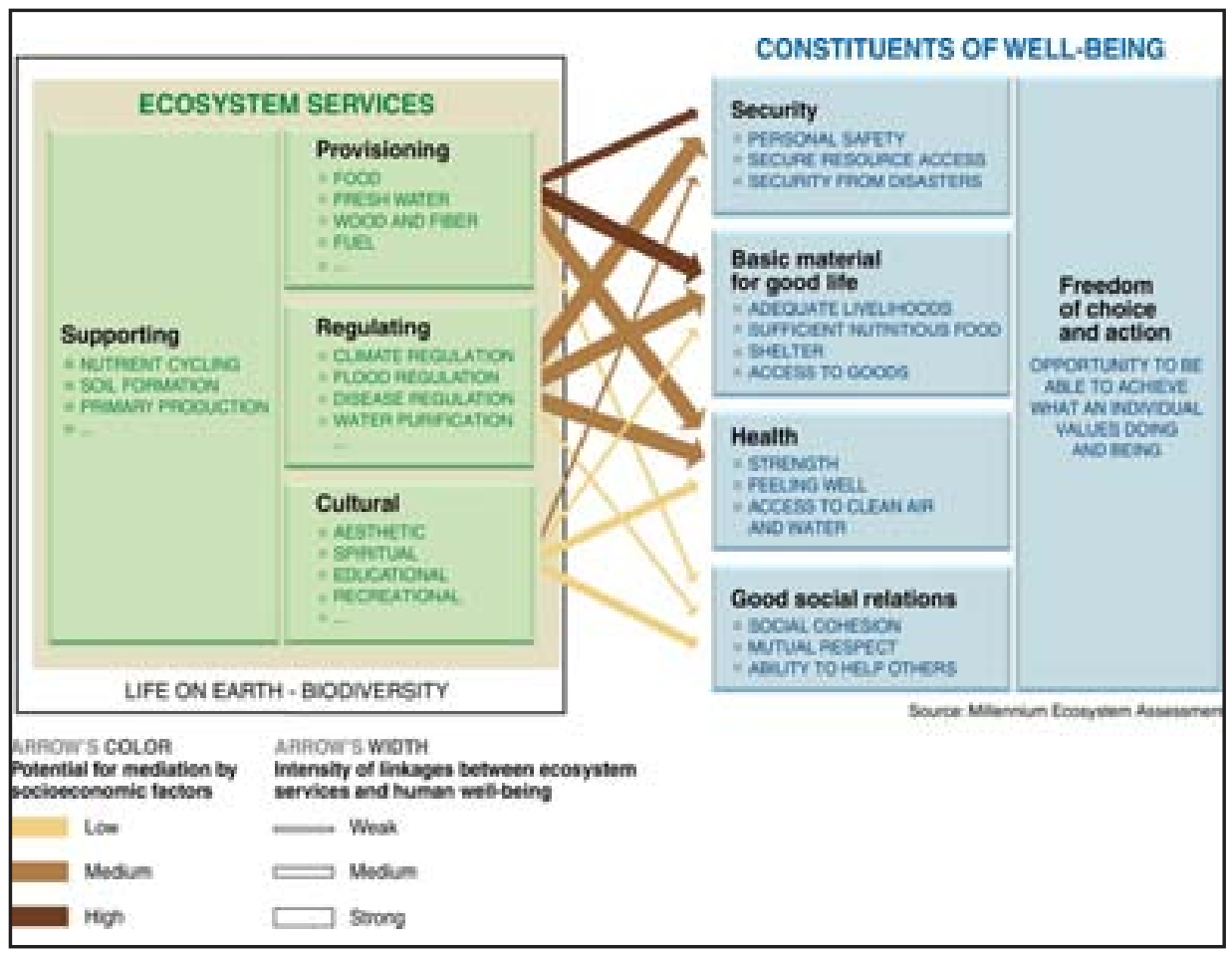

Figure 2.3 The links between biodiversity conservation, ecosystem services and human wellbeing

Source: Millennium Ecosystem Assessment (2005a).

\section{Conservation Targets}

The Guide proposes a target for the conservation of 75 per cent of the culturally iconic red-gum floodplain forests in good condition (MDBA 2010a:117). There are a number of issues associated with this choice of target. First, it is not clear why 75 per cent was chosen, and as it countenances the permanent loss of one-quarter of these forests, it is inconsistent with the Ramsar Convention's requirement to maintain the ecological character of wetlands, especially designated Ramsar sites. Second, it is unclear why no targets are considered 
for other wetland types. Indeed, as black-box floodplain forests are at higherelevation (less frequently flooded) parts of the floodplains, conserving only a portion of the red-gum forests implies there will not be enough water to conserve many black-box forests. Third, this 75 per cent target amounts to a lower level of ambition for conservation of red-gum forests at Barmah-Millewa and Chowilla, while in The Living Murray program, targets to conserve the entire area had been proposed (MDBMC 2003; Pittock et al. 2010). It appears that not only is the red-gum target an unsupported compromise but is also used to justify focusing on a lower level of reallocation of water for the environment.

\section{Water Reallocation}

The Guide outlines hydrological modelling that recommends reallocation of between 3000 and $7600 \mathrm{GL} / \mathrm{yr}$, on average, to the environment (MDBA 2010a:756). This is based on an assumption that adequate environmental flows for 18 major wetlands designated as 'indicator assets' will sustain ecological functions and a great many of the 30000 wetlands throughout the Basin. The MDBA (2010a:74) admits, however, that with an extra $3000 \mathrm{GL} / \mathrm{yr}$, the River Murray would still be ranked as having a 'poor' environmental-flow condition, and the environmental objectives of the Water Act are achieved only with an optimistic 'long term return to wetter conditions across the Basin' (p. 75). Further, only a $4000 \mathrm{GL} / \mathrm{yr}$ reallocation is likely to achieve the 75 per cent red-gum target (MDBA 2010a:118).

'Giving effect to relevant international agreements' is acknowledged only in relation to a reallocation of $7600 \mathrm{GL} / \mathrm{yr}$. The MDBA then declares, however, that reallocation of more than $4000 \mathrm{GL} / \mathrm{yr}$ would have unacceptable socioeconomic impacts, and consequently it countenances reallocation of just 3000-4000 GL/ yr on average (MDBA 2010a:100, 107). This contravenes the requirement in the Water Act to first give effect to international agreements and determine an environmentally sustainable level of take, and only then optimise the environmental, social and economic outcomes (Commonwealth of Australia 2008).

As a result of the proposed lower levels of water reallocation, the Guide suggests that there could be trade-offs between adequate watering of the Coorong and Lower Lakes Ramsar site versus upstream red-gum floodplain forests, and between watering red-gum versus black-box floodplain forests (MDBA 2010a:126). Neither of these measures would maintain the ecological character of designated Ramsar sites. The MDBA also proposes the politically beguiling, but environmentally risky, option of using engineering measures to apply less water to more efficiently maintain large areas of wetlands (as discussed earlier). 


\section{Management of Climate Risks}

A further concern in the Guide is the limited consideration given to managing risks of reduced water availability arising from climate change. There are three aspects to this question - namely, whether: a) sufficient reductions in water allocations are considered to account for potential reductions of inflows; b) the adaptation measures adopted adequately spread risk; and c) new, climate change-related inflow interception activities are adequately regulated.

The MDBA has based its consideration of climate-induced hydrological changes on CSIRO modelling for the period 1990-2030 that suggested that surfacewater availability could increase by up to 7 per cent in an extreme wet scenario, decrease by as much as 12 per cent with a median forecast, or decline by 24 per cent in an extreme dry scenario (CSIRO 2008). In the Guide, the MDBA (2010a:33-4) then proposes a reduction of water allocations of just 3 per cent based on the median forecast - halved on the basis that part of the impact should already be present, and halved again to reflect the envisaged 10-year (2011-21) life of the Basin Plan (even though Victorian implementation would commence only in 2019 and finish in 2024). This approach is questionable for a number of reasons. First, good risk management considers management for less likely but more catastrophic events. Second, the experience of climate-change impacts on water thus far in Australia has not entailed a linear reduction but rather a 'step-change' (for instance, in south-west Western Australia), and there is every possibility that such a change is under way in south-eastern Australia (CSIRO 2010). In this event, a 3 per cent reduction in water extractions by 2011-24 is likely to be most inadequate.

By default, the Guide proposes managing climate risks almost entirely by water reallocations and environmental flows. Such flows are highly vulnerable to poor government decision making in periods of water scarcity (as discussed earlier). Environmental flows are an important response but far from the only measure that would aid adaptation of freshwater ecosystems to climate change (Palmer et al. 2008; Pittock and Finlayson 2011). Unfortunately, a number of adaptation measures - such as re-establishment of riparian vegetation-lie outside the mandate of the Basin Plan (MDBA 2010a), but others should be considered and would help spread risk by maintaining refuges using approaches that do not require positive management intervention. One key measure would be the reservation of remaining free-flowing rivers and tributary streams from further water-resources development so as to maintain natural flow regimes and other ecological processes (Pittock and Finlayson 2011). Another could be to protect gaining river reaches as refuges from excessive groundwater extraction (CSIRO 2008; Pittock and Finlayson 2011). 
Policy responses to climate change are likely to substantially change water use in the Basin, and the Basin Plan needs to ensure all major and emerging inflowinterception activities are adequately regulated. The Guide adopts a status-quo perspective - for instance, modelling only the likely impact of currently planned forestry plantations (MDBA 2010a:51). Yet all sides of politics in Australia have proposed mechanisms to subsidise landholders to undertake afforestation for carbon sequestration (ALP 2010; LPA 2010) without considering the substantial reductions of inflows that could ensue (Herron et al. 2002). Similarly, water demand for climate-related technologies such as bio-char, solar-thermal power plants and carbon capture and storage is likely to change water use in the Basin (Inhaber 2004; Smart and Aspinall 2009).

The MDBA (2010a:34) has also adopted 'a principle of equitable sharing of any reductions in water availability between consumptive and environmental uses' under future climate conditions. There is no doubt that this would be substantially better for the environment than the current water-allocation rules that overwhelmingly favour consumptive users when water is scarce (CSIRO 2008). This is not, however, consistent with the NWI agreement that water entitlement-holders should bear this risk (COAG 2004:s. 48). It also would not meet Australia's obligation under the Ramsar Convention to maintain the ecological character of all designated Ramsar sites while ever it is physically possible to do so, unless the Government declares that it cannot in the 'urgent national interest' (Pittock et al. 2010). In other words, in the event of climateinduced reductions in water availability, Australia is obliged to give priority to maintaining the Ramsar wetlands.

\section{Conclusions}

There are major consequences of the MDBA's proposals to manage the Basin with only a minimal reallocation of an extra 3000-4000 GL/yr on average of water for the environment-namely

- large areas of wetlands cannot be sustained, including about one-quarter of the red-gum forests, extensive areas of black-box forest, and trade-offs between maintaining different wetlands would be necessary

- the system would be managed without any substantial ecological capacity to withstand the impacts of unanticipated events, such as a step-change reduction in water inflows due to climate change or changes in inflowinterception activities in the catchment

- increasingly, conservation of key sites would rely on constant intervention through environmental-water demand-management measures when State government authorities in Australia have shown themselves to be incapable 
of reliably implementing such freshwater-conservation measures by suspending previous water-sharing agreements (NWC 2009)

- Australia would continue to be in breach of a number of its international obligations under the CBD and Ramsar, such as maintaining the ecological character of all of the designated Ramsar sites.

Compared with the current, deplorable situation, there is no doubt that the freshwater ecosystems of the Basin will be in better condition with a reallocation of water to the environment and with new rules for sharing future water losses between consumptive users and the environment (Pittock et al. 2010). The Water Act, however, in requiring the Basin Plan to give effect to relevant international agreements, sets a threshold for better conservation of wetlands that the compromise proposals and trade-offs mooted in the Guide to the proposed Basin Plan fail to meet. In particular, omitting measures to conserve a representative range of wetland types and the envisaged loss of ecological character from large areas of Ramsar sites abrogate Australia's international obligations.

The MDBA still has the opportunity to revise its policies to recommend a Basin Plan in 2011 that would meet Ramsar Convention obligations and better conserve freshwater ecosystems in the Basin. We recommend seven key changes

1. identification and valuation of the full range of ecosystem services in the Basin as a basis for better decision making

2. assessment of wetlands against both the diversity of wetland types established by the Ramsar Convention and their nine site-listing criteria, to ensure that an adequate and representative range of wetland biota will be sustained across the Basin in key ecological assets

3. reallocation of sufficient water - in the 4400-7600 GL/yr on average rangeto maintain the ecological character of all areas of the 16 designated Ramsar wetlands, as well as key ecological assets that are not located on main rivers

4. identification and protection of remaining free-flowing tributary rivers and of river reaches that receive net inflows from groundwater ('gaining reaches') as additional means of conserving freshwater biota and for climate-change adaptation that are largely independent of management interventions

5. more robust management of climate change-induced risks to water availability, including greater reallocation of water to the environment, implementation of the NWI policy for future reductions in water entitlements to be borne by water entitlement-holders for reductions due to climate change; and provision for contingency measures that would be triggered from 2015 should climate change severely reduce water availability 
6. proactive management of existing water infrastructure to ensure that water quality and ecosystem functions are improved, including control of thermal pollution and reinstatement of fish passage

7. identification of additional measures for research by the MDBA in the 201120 period, such as conservation of groundwater-dependent ecosystems and climate-change adaptation options, to ensure that the subsequent iteration of the Basin Plan is further improved.

A reform plan that again compromises on allocation of adequate water to sustain the Basin's wetlands will result in ongoing environmental degradation, another crisis in the next, inevitable drought, and demands for further reform. We argue that implementing these stronger environmental measures, based on the Ramsar Convention's provisions, will provide greater certainty for people and nature, and enhance the possibility of maintaining healthy communities across the Basin.

\section{References}

Alluvium 2010, Key ecosystem functions and their environmental water requirements, Report by Alluvium for Murray-Darling Basin Authoriy, Canberra.

Australian Bureau of Statistics (ABS), Australian Bureau of Agricultural and Resource Economics (ABARE) and Bureau of Rural Sciences (BRS) 2009, Socioeconomic context for the Murray-Darling Basin-descriptive report, Murray-Darling Basin Authority, Canberra.

Australian Labor Party (ALP) 2010, Carbon farming fact sheet, Australia Labor Party, Canberra.

Commonwealth of Australia 2007, Water Act 2007, No. 137 (2007), Commonwealth of Australia, Canberra.

Commonwealth of Australia 2008, 'Water Act 2007', in Attorney-General's Department (ed.), Act No. 137 as amended, Commonwealth of Australia, Canberra.

Commonwealth Scientific and Industrial Research Organisation (CSIRO) 2008, Water availability in the Murray-Darling Basin, A Report from CSIRO to the Australian Government, Canberra. 
Commonwealth Scientific and Industrial Research Organisation (CSIRO) 2010, Climate Variability and Change in South-Eastern Australia: A synthesis of findings from Phase 1 of the South Eastern Australian Climate Initiative (SEACI), CSIRO, Canberra.

Connell, D. 2007, Water Politics in the Murray-Darling Basin, The Federation Press, Leichardt, NSW.

Convention on Biological Diversity (CBD) 2004a, Decision VII/4. Biological Diversity of Inland Waters, Convention on Biological Diversity, Montreal.

Convention on Biological Diversity (CBD) 2004b, Decision VII/28. Protected Areas, Articles 8(a)-(e), Convention on Biological Diversity, Montreal.

Council of Australian Governments 2004, Intergovernmental Agreement on a National Water Initiative, Council of Australian Governments, Canberra.

Davies, P. E., Harris, J. H., Hillman, T. J. and Walker, K. F. 2010, 'The sustainable rivers audit: assessing river ecosystem health in the Murray-Darling Basin, Australia', Marine and Freshwater Research, vol. 61, pp. 764-77.

Department of Environment, Heritage, Water and the Arts (DEWHA) 2009, Australian Ramsar Wetlands, Department of Environment, Heritage, Water and the Arts, Commonwealth of Australia, Canberra.

Falkenmark, M. and Molden, D. 2008, 'Wake up to realities of river basin closure', International Journal of Water Resources Development, vol. 24, pp. 201-15.

Finlayson, C. M., Gitay, H., Bellio, M. G., van Dam, R. A. and Taylor, I. 2006, 'Climate variability and change and other pressures on wetlands and waterbirds: impacts and adaptation', in G. C. Boere, C. A. Galbraith and D. A. Stroud (eds), Waterbirds Around the World, The Stationery Office, Edinburgh.

Grafton, Q. and Hussey, K. 2007, 'Buying back the living Murray: at what price?', Australian Journal of Environmental Management, vol. 14, pp. 74-81.

Herron, N., Davis, R. and Jones, R. 2002, 'The effects of large-scale afforestation and climate change on water allocation in the Macquarie River catchment, NSW, Australia', Journal of Environmental Management, vol. 65, pp. 369-81.

Inhaber, H. 2004, 'Water use in renewable and conventional electricity production', Energy Sources, vol. 26, pp. 309-22. 
Intergovernmental Science-Policy Platform on Biodiversity and Ecosystem Services (IPBES) 2010, Intergovernmental Science-Policy Platform on Biodiversity and Ecosystem Services, United Nations Environment Programme, Nairobi.

Jones, G., Hillman, T., Kingsford, R., McMahon, T., Walker, K., Arthington, A., Whittington, J. and Cartwright, S. 2002, Independent report of the Expert Reference Panel on environmental flows and water quality requirements for the River Murray system, Cooperative Research Centre for Freshwater Ecology, Canberra.

Kingsford, R. T., Brandis, K., Thomas, R. F., Crighton, P., Knowles, E. and Gale, E. 2004, 'Classifying landform at broad spatial scales: the distribution and conservation of wetlands in New South Wales, Australia', Marine and Freshwater Research, vol. 55, pp. 17-31.

Kingsford, R. T., Fairweather, P. G., Geddes, M. C., Lester, R. E., Sammut, J. and Walker, K. F. 2009, Engineering a Crisis in a Ramsar Wetland: The Coorong, Lower Lakes and Murray Mouth, Australia, Australian Wetlands and Rivers Centre, University of New South Wales, Sydney.

Leslie, J. 2005, Deep Water: The epic struggle over dams, displaced people, and the environment, Farrar, Straus \& Giroux, New York.

Liberal Party of Australia (LPA) 2010, The Coalition's Direct Action Plan: Environment and climate change, Liberal Party of Australia, Canberra.

Millennium Ecosystem Assessment (MEA) 2005a, Ecosystems and Human WellBeing: Synthesis, Island Press, Washington, DC.

Millennium Ecosystem Assessment (MEA) 2005b, Ecosystems and Human WellBeing: Wetlands and water synthesis, World Resources Institute, Washington, DC.

Murray-Darling Basin Authority (MDBA) 2010a, Guide to the proposed Basin Plan. Volume 1: Overview, Murray-Darling Basin Authority, Canberra.

Murray-Darling Basin Authority (MDBA) 2010b, Guide to the proposed Basin Plan. Volume 2: Technical background, Murray-Darling Basin Authority, Canberra.

Murray-Darling Basin Ministerial Council (MDBMC) 2003, Murray-Darling Basin Ministerial Council communiqué, 14 November 2003, Murray-Darling Basin Commission, Canberra. 
Basin Futures

National Water Commission (NWC) 2009, Australian Water Reform 2009: Second biennial assessment of progress in implementation of the National Water Initiative, September 2009, National Water Commission, Canberra.

Natural Resources Commission (NRC) 2009, Riverina bioregion regional forest assessment river red gums and woodland forests, Final assessment report, NSW Natural Resources Commission, Sydney.

Overton, I. 2010, 'Ecological outcomes of flow regimes in the Murray-Darling Basin', Distilled, <http://www.nwc.gov.au/www/html/2750-ecologicaloutcomes-of-flow-regimes-in-the-murray-darling-basin.asp?intSiteID=1] >

Overton, I. C., Colloff, M. J., Doody, T. M., Henderson, B. and Cuddy, S. M. (eds) 2009, Ecological Outcomes of Flow Regimes in the Murray-Darling Basin, CSIRO, Canberra.

Palmer, M. A., Reidy Liermann, C. A., Nilsson, C., Flörke, M., Alcamo, J., Lake, P. S. and Bond, N. 2008, 'Climate change and the world's river basins: anticipating management options', Frontiers in Ecology and the Environment, vol. 6 .

Pearce, F. 2006, When the Rivers Run Dry, Eden Project Books, London.

Pittock, J. and Finlayson, C. M. 2011, 'Australia's Murray-Darling Basin: freshwater ecosystem conservation options in an era of climate change', Marine and Freshwater Research, vol. 62, pp. 232-243.

Pittock, J. and Lankford, B. A. 2010, 'Environmental water requirements: demand management in an era of water scarcity', Journal of Integrative Environmental Sciences, vol. 7, pp. 75-93.

Pittock, J., Finlayson, C. M., Gardner, A. and McKay, C. 2010, 'Changing character: the Ramsar Convention on Wetlands and climate change in the Murray-Darling Basin, Australia', Environment and Planning Law Journal, vol. 27.

Pittock, J., Hansen, L. J. and Abell, R. 2008, 'Running dry: freshwater biodiversity, protected areas and climate change', Biodiversity, vol. 9, pp. $30-8$.

Powell, J. L. 2008, Dead Pool: Lake Powell, global warming and the future of water in the west, University of California Press, Berkeley and Los Angeles.

Productivity Commission 2010, Market mechanisms for recovering water in the Murray-Darling Basin, March, Final report, Productivity Commission, Melbourne. 
Ramsar 2005, Resolution IX.1 Annex A: A conceptual framework for the wise use of wetlands and the maintenance of their ecological character, Ramsar Convention on Wetlands, Gland, Switzerland.

Ramsar 2008a, Resolution X.15 Describing the ecological character of wetlands, and data needs and formats for core inventory: harmonized scientific and technical guidance, Ramsar Convention on Wetlands, Gland, Switzerland.

Ramsar 2008b, Strategic Framework and Guidelines for the Future Development of the List of Wetlands of International Importance of the Convention on Wetlands (Ramsar, Iran, 1971), Ramsar Convention on Wetlands, Gland, Switzerland.

Ramsar 2009a, Convention on Wetlands of International Importance Especially as Waterfowl Habitat. Ramsar (Iran), 2 February 1971, UN Treaty Series No. 14583, As amended by the Paris Protocol, 3 December 1982, and Regina Amendments, 28 May 1987, Ramsar Convention on Wetlands, Gland, Switzerland.

Ramsar 2009b, Information sheet on Ramsar wetlands (RIS), Ramsar Convention on Wetlands, Gland, Switzerland.

Smart, A. and Aspinall, A. 2009, Water and the Electricity Generation Industry. Implications of use, National Water Commission, Canberra.

United Nations 1992, Convention on Biological Diversity (with annexes). Concluded at Rio de Janerio on 5 June 1992, Treaty Series No. 30619, Multilateral, United Nations, New York. 